\title{
Retınal Examınatıon For Plaque Burden
}

\author{
Umur Kayabasi* \\ Department of Neuroophthalmology, Uskudar University, Turkey
}

Submission: September 10, 2017; Published: October 27, 2017

*Corresponding author: Umur Kayabasi, Department of Neuroophthalmology,Uskudar University, Turkey

\section{Mini Review}

A recentarticleauthoredby an experienced team of author ssuggests that retinal amyloid burden is correlated with brain amyloid burden in Alzheimer's disease(AD). Moreover, it is stated that retinal amyloid plaques appear before they start to invade the hippo campus [1]. Screening amyloid beta (AB) in the retina is definitely a major break through in Alzheimer's disease (AD). Comparing retinal amyloid burden with brain amyloid is even going one step further in thetrials for the early diagnosing of AD. Imaging the retina is easy, non-invasive, cheapand does not involve radiation.

But, there are two important questions that come to mind when considering the recent

developments in AD studies:

1. Mayo Clinic study of thousands of brains revealed Tau as driver of $\mathrm{AD}$ [2]. So, do we need to show Tau protein along with $\mathrm{AB}$ in the retina to be able to make correct assumptions about the disease process?

2. Postmortem studies have demonstrated that people with $\mathrm{AD}$ have far more $\mathrm{AB}$ plaques in their brains than healthy people. But, roughly $30 \%$ of peoplewithoutanysigns of dementia have brains "chock-full" of $A B$ at autopsy [3]. So, the presence of $\mathrm{AB}$ may not be enough to prove that any patient will develop the disease in the future.

Increased deposition of $\mathrm{AB}$ iso forms have been described on photo receptor outer segments and along the RPE-Bruch's membrane interface in the aging human and mouse retina [4]. Another study using immuno staining revealed $A B$ on photo receptor outer segments all through the retina in humans as an ageing process [5]. This deposition process may very well be only a sign of ageingand not relatedto AD.

Analyses of drusencomponents have shown deposition of $A B$ with in vesicles in eyes of age related macular degeneration (AMD) patients .We also managed to show $\mathrm{AB}$ in drusen of AMD patients [6]. A better approach may be to demonstrate and quantify both proteins in the retina $[7,8]$. We have been able to image Tau aggregates in the retina of live patients. (Figure $1 \&$ 2). Tau deposits have been found in the temporal lobe early in the disease which proves that Tau PET imaging is also necessary to be able to correlate the abnormal protein burdenwith brain plaques [3].

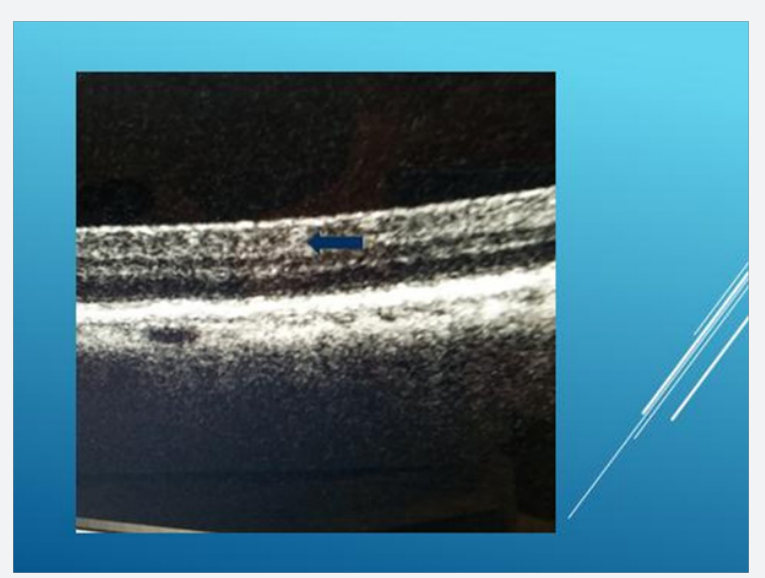

Figure 1: 


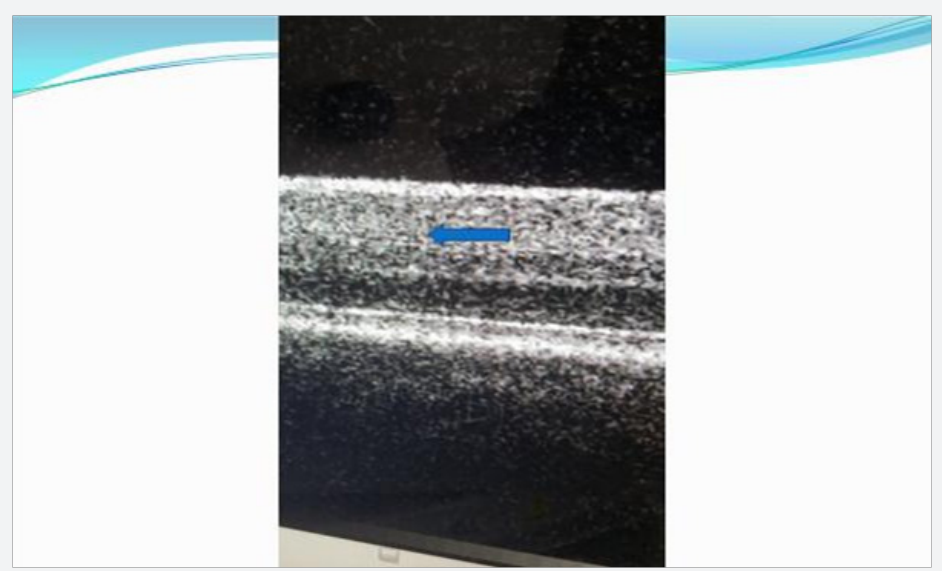

Figure 2:

\section{Conclusion}

Recent studies confirmed that combination of Tau and $\mathrm{AB}$ aggregates caused the disease. Another proof of this theory is the unsuccessful results of $\mathrm{AB}$ aimed therapies in $\mathrm{AD}$. We believe more collaborative work is necessary for the definite answers to the remaining questions.

\section{References}

1. Koronyo Y (2017) Retinal amyloid pathology and proof-ofconceptimagingtrial in Alzheimer's disease. JCI Insight 2(16): e93621.

2. Murray M (2015) Study of Thousands of Brains Reveals Tau as Driver of Alzheimer's Disease. Mayo Clinic Alumni Association.

3. Jones DT (2016) Cascading network failure across the Alzheimer's disease spectrum. Brain 139(2): 547-562.
4. Shah TM, Gupta SM, Chatterjee P, Campbell M, Martins RN (2017) Beta-amyloid sequelae in the eye: a critical review on its diagnostic significance and clinical relevance in Alzheimer's disease. Mol Psychiatry 22(3): 353-363.

5. Kam JH, Lenassi E, Jeffery G (2010) Viewing Ageing Eyes: Diverse Sites of Amyloid Beta Accumulation in the Ageing Mouse Retina and the UpRegulation of Macrophages. PLoS One 5(10): e13127.

6. Kayabasi U, Sahbaz I (2017) Beta Amyloid in Age-RelatedMacularDegen erationLesions in a PatientwithAlzheimer'sDisease. EC Ophthalmology $7(1): 18-21$

7. Kayabasi U (2016) Tau in the Retina. EC Neurology 3(5): 493-499.

8. Kayabasi U (2017) Retinal Examination by OCT to Reveal Neuro degeneration in the Brain. EC Ophthalmology 6(5):139-140.

\begin{tabular}{|l|}
\hline \multicolumn{1}{|c|}{ Your next submission with Juniper Publishers } \\
will reach you the below assets \\
- Quality Editorial service \\
- Swift Peer Review \\
- Reprints availability \\
- E-prints Service \\
- Manuscript Podcast for convenient understanding \\
- Global attainment for your research \\
- Manuscript accessibility in different formats \\
( Pdf, E-pub, Full Text, Audio) \\
- Unceasing customer service \\
Track the below URL for one-step submission \\
https://juniperpublishers.com/online-submission.php \\
\hline
\end{tabular}

